IRSTI 14.35.05+14.35.07

\author{
Mynbayeva A. \\ Doctor of pedagogical Sciences, Professor \\ Al-Farabi Kazakh National University \\ Almaty, Kazakhstan \\ e-mail: Aigerim.Mynbaeva@kaznu.kz
}

\title{
ART TEACHING AND DEVELOPING CREATIVITY IN STUDENTS: APPROACHES AND MODELS
}

The article summarizes findings of the research conducted by the Ministry of Education and Science of the Republic of Kazakhstan, «Developing Creativity \& Creative Abilities in Students as a Factor of Increasing the Kazakhstan's Intellectual Capacity». The aim of the research is to design models for creativity development in students, including on the basis of Art Teaching, the development and testing of Art Technologyin the course of teaching students. In the article the following models are given: (1) creativity development in students, (2) synthesis of Art Technology and Psychodrama in playing complex human situations through Puppet Therapy. The model of creativity development in students includes 7 blocks - public order, target, methodological, informative, diagnostic, instrumental, and effective one. It it focused on the following areas (1) use of innovative teaching methods, (2) use of Art Technology for capacity building in students, (3) technology of Puppet Therapy\&Psychodrama synthesis. A model of Art Technology\&Psychodrama synthesis is proposed by means of shared goals, objectives, principles, functions, and content. The technology of staging complex life situations through Puppet Therapy is described in a step-by-step manner. The first stage is about warming-up: the removal of blocks, exercises in teaching artistry, group ice breaking. The second stage is the core one. During it, the key issue is put at the center, making a doll from improvised material such as newspapers, magazines, role playing around the issue. The third stage is the final one. There occurs discussion and review of the role play. In conclusion section of the article, the use of this technology is reviewed, including evaluation of the technology by students.

Key words: art pedagogy, creativity, pedagogical modeling, art therapy, puppet therapy.

$$
\begin{gathered}
\text { Мынбаева А.К. } \\
\text { Аоктор педагогических наук, профессор, } \\
\text { Казахский национальный университет имени аль-Фараби, } \\
\text { Республика Казахстан, г. Алматы, е-mail: Aigerim.Mynbaeva@kaznu.kz }
\end{gathered}
$$

\section{Арт-педагогика и развитие креативности студентов: подходы и модели}

Статья обобщает результаты исследования НИР МОН РК №1763/ГФ4 «Развитие креативности и творческих способностей стулентов как фактор повышения интемлектуального потенциала Казахстана». Цель исследования - проектирование моделей развития креативности студентов, в том числе на основе арт-педагогики, разработка и апробация арт-технологий в процессе обучения студентов. В статье приведены модели: (1) развития креативности студентов, (2) синтеза арт-технологий и психодрамы в проигрывании сложных жизненных ситуаций человека через куклотепарию. Модель развития креативности студентов вк^ючает 7 блоков - общественного заказа, целевой, методологический, содержательный, диагностический, инструментальный, результативный. В нее включены направления: (1) использование инновационных методов обучения, (2) применение арт-технологий Аля развития студентов, (3) технология синтеза куклотерапии и психодрамы. Предложена модель синтеза арт-технологий и психодрамы путем интегрированных целей, задач, принципов, функций, содержания. Пошагово описана технология проигрывания сложных жизненных ситуаций через куклотерапию. Первый этап - разминочный: снятие зажимов, упражнения по педагогическому артистизму, раскрепощение группы. Второй этап - основной. Во время него проиходит выдвижение проблемной ситуации, создание из под- 
ручного материала газет, журналов и т.п. кук^, инсценировка проблемы. Третий - зак^ючительный. Происходит обсуждение и анализ инсценировки. В зак^ючении статьи проведен анализ использования данной технологии, в том числе приведены оценки технологии студентами.

Ключевые слова: арт-педагогика, креативность, педагогическое моделирование, арт-терапия, кук^отерапия.

Мынбаева А.К.

педагогика ғылымдарының докторы, профессор, әл-Фараби атындағы Қазақ ұлттық университеті, Қазақстан Республикасы, Алматы қ., е-mail: Aigerim.Mynbaeva@kaznu.kz

\title{
Арт-педагогика және студенттердің креативтікігін дамыту: тұрғылар мен модельдер
}

\begin{abstract}
Мақалада «Студенттердің креативтілігін және шығармашылық қабілеттіліктерін дамыту Қазақстанның интемлектуалдық әлеуетін арттырудың факторы ретінде» деп аталатын ҚР БжҒМ №1763/ГФ4 ҒҒЖ зерттеу нәтижелері жинақталады. Зерттеудің мақсаты - студенттердің креативтілігін дамытумоделін жобалау, соның ішінде оқу үлерісінде студенттердің арт-педагогика негізінде арт-технологияларды қолдануының әзірлемесін жасау және оны байқаудан өткізу. Мақалада (1) студенттердің креативтілігін дамыту, (2) адамның күрделі өмірлік жағдайларын арт-технология және психодрама синтезінде қуыршақ терапиясы арқылы ойнау модельдері көрсетіледі. Студенттердің креативтілігін дамыту моделі қоғамдық тапсырыс, мақсатты, әдіснамалық, мазмұндық, диагностикалық, құралдық, нәтижелілік сияқты 7 модельден тұрады. Онда (1)оқытудың инновациялық, әдістерін қолдану, (2) студенттерді дамытуда арт-технологияны пайдалану, (3) арт-технология және психодрама синтезі тәрізді бағыттар қамтылған. Мақсат, міндет, ұстанымдар, функциялар және мазмұнның кіріктірілуіндегі арт-технология және психодрама синтезінің моделі ұсынылған. ААамның күрделі өмірлік жағдайларын қуыршақ терапиясы арқылы ойнаудың қадамдары сипатталған. Бірінші кезең - бой қыздыру; қысымдарды шығару; педагогикалық артистизм бойынша жаттығулар; топтарды басыбайлықтан босату. Екінші кезең-негізгі. Оның уақытында мәселелік жағдаятты көрсету, қолда бар материалдар-газет, журналдар және т.б. қуыршақ, мәселенің инсценировкасы жасалады. Үшінші - қорытынды. Инсценировканы талқылау және талдау жүргізіледі. Мақаланың қорытындысында аталған технологияны қолданудың, соның ішінде студенттердің технологияны бағалауы талданған.

Түйін сөздер: арт-педагогика, креативтілік, педагогикалық модельдеу, арт-терапия, қуыршақ терапия.
\end{abstract}

\section{Introduction}

According to the State Program for the Development of Education and Science in the Republic of Kazakhstan for 2016-2019, 'The current upgrading stage of the Kazakh system of education and science implies, among others, the opportunity to develop research and creative competence' [1]. Such goal outlines the need to establish creative and research environment within educational institutions to foster creativity development in students.

In this article, we will summarize comprehensive findings of the research project conducted by the Research Institute under the Ministry of Education and Science of the Republic of Kazakhstan 'Developing Creativity and Creative Abilities in Students as a Factor of Increasing Kazakhstan's Intellectual Capacity' [2].

\section{Materials and Methods}

Based on the use of systemic and comprehensive approaches and modeling method, a multicomponent model of creativity development in students as a factor of strengthening student intellectual ca- pacity has been designed. On the basis ofArt Teaching and Art Therapy, Psychodrama, a technology of Puppet Therapy has been designed to play professional and life situations. The technology has been tested and embedded in the learning process of AlFarabi Kazakh National University.

Designing a model for creativity development in students

Analysis of the definition of creativity [3] enabled us to conclude that the definition by N. F. Vishnyakova is the most appropriate for our research: 'Creativity is a set of intellectual and personal abilities of a person contributing to independent problem setting, generating a large number of creativeideas and non-standard ways of solving them' [4]. We have developed a multicomponent structure and content model for creativity development in students as a factor of strengthening student intellectual capacity.

A poly-component structural content model for the development of creativity and creative abilities of students has been developed. The model includes the following blocks (Figure 1): 
- state and public order for the development of the intellectual potential of the individual; conformity to the world trend of development of human capital, social capital, sustainable development of society;

- target block: the objective is to develop the creativity and creative abilities of the students' personality; tasks are the disclosure of the hidden creative potential of students; the formation of positive motives for the development of creative abilities; the formation of a positive Self-image;

- methodological block: methodological approaches are personal-oriented, activity-oriented and environmental approaches, art pedagogical and art historical, aesthetic approaches; principles of creativity development: humanization, cooperation, openness to new tasks, creative flashes, developing and person oriented orientation, flexibility, emotionality of the educational environment, modeling of creative events and images; the principles of creating an art environment or art laboratory: catalog feasibility (i.e. continuous unity of ethical and aesthetic elements); cathartism (i.e. ability to activate an optimistic sense of personal dignity); creativity or motivation for creativity in everything (the law of the three $\langle\mathrm{K} »$ ), according to Mirzaliyeva E.B.[5]; aestheticization, ethification, intellectualization and involution;

- content block: contains the structure of students' creative abilities in the form of value and motivational, cognitive, technological components. Development is reflected in the variable programs of work with students and schoolchildren;

- the diagnostic block: includes trajectories of diagnosing students' creativity. Here one can simply use a battery of known tests for creativity and creative abilities, or projected diagnostic cards:

1) The first version of the expanded diagnostic of the creativity of student youth includes 5 stages and consists of 8 test methods:

a) The questionnaire «Determining the types of thinking and creativity» by J. Bruner;

b) Test for the diagnosis of creativity and creative potential of the individual;

c) Test for the level of development of the imagination;

d) Test «Artist-Thinker»;

e) Methods of diagnosing an individual for motivation to avoid failures of T. Ehlers;

f) Diagnosis of achievement motivation (A.Mehrabian);

g) Methodology for diagnosing the degree of readiness for risk by A.Shubert;

h) Test «Leading Representative System» S. Efremtseva.
2) The second version of the expanded diagnostic of the creativity of student youth includes 3 stages and consists of 3 test methods:

Test «Diagnosis of personal creativity» by E.E. Tunic;

Test «Creativity» by N. Vishnyakova;

Test on the personality type by Myers-Briggs (MBTI).

3) The third version of the expanded diagnostic of the creativity of student youth includes 5 stages and consists of 12 test methods:

a) «Determining the types of thinking and creativity» by J. Bruner

b) Test «Diagnosis of personal creativity» by E.E. Tunic;

c) Test «Creativity» (author: N. Vishnyakova);

d) «The test for the diagnosis of creative potential and creativity»;

e) Personality type test according to MyersBriggs (MBTI);

f) «The test for the level of development of the imagination»;

g) Test «Artist-Thinker»;

h) Methods of diagnosing the individual for motivation to avoid failures by T. Ehlers;

i) Test for achievement motivation by $\mathrm{A}$. Mehrabian,

j) The AA questionnaire. Rean «Motivation for success and fear of failure» (EOR);

k) Diagnostics of the degree of readiness for risk by A.M.Schubert;

1) Test «Leading Representative System».

h) Methods of diagnosing the individual for motivation to avoid failures by T. Ehlers;

i) Test for achievement motivation by $\mathrm{A}$. Mehrabian,

j) The AA questionnaire. Rean «Motivation for success and fear of failure» (EOR);

k) Diagnostics of the degree of readiness for risk by A.M.Schubert;

1) Test «Leading Representative System».

Model for the development of creativity and creative abilities of students

The instrumental block includes methods and forms of creativity development. They are also quasivariable. Methods for the development of creativity are: version 1 - innovative methods of teaching students; version 2 - art-technology of development of students; version 3 - art-therapeutic methods and technologies, including the technology of synthesis of puppet therapy and psychodrama. Forms of creative abilities and creativity development are: seminars-trainings, exhibitions, art-laboratory work, tutorial hours; museum aesthetic learning environment. 


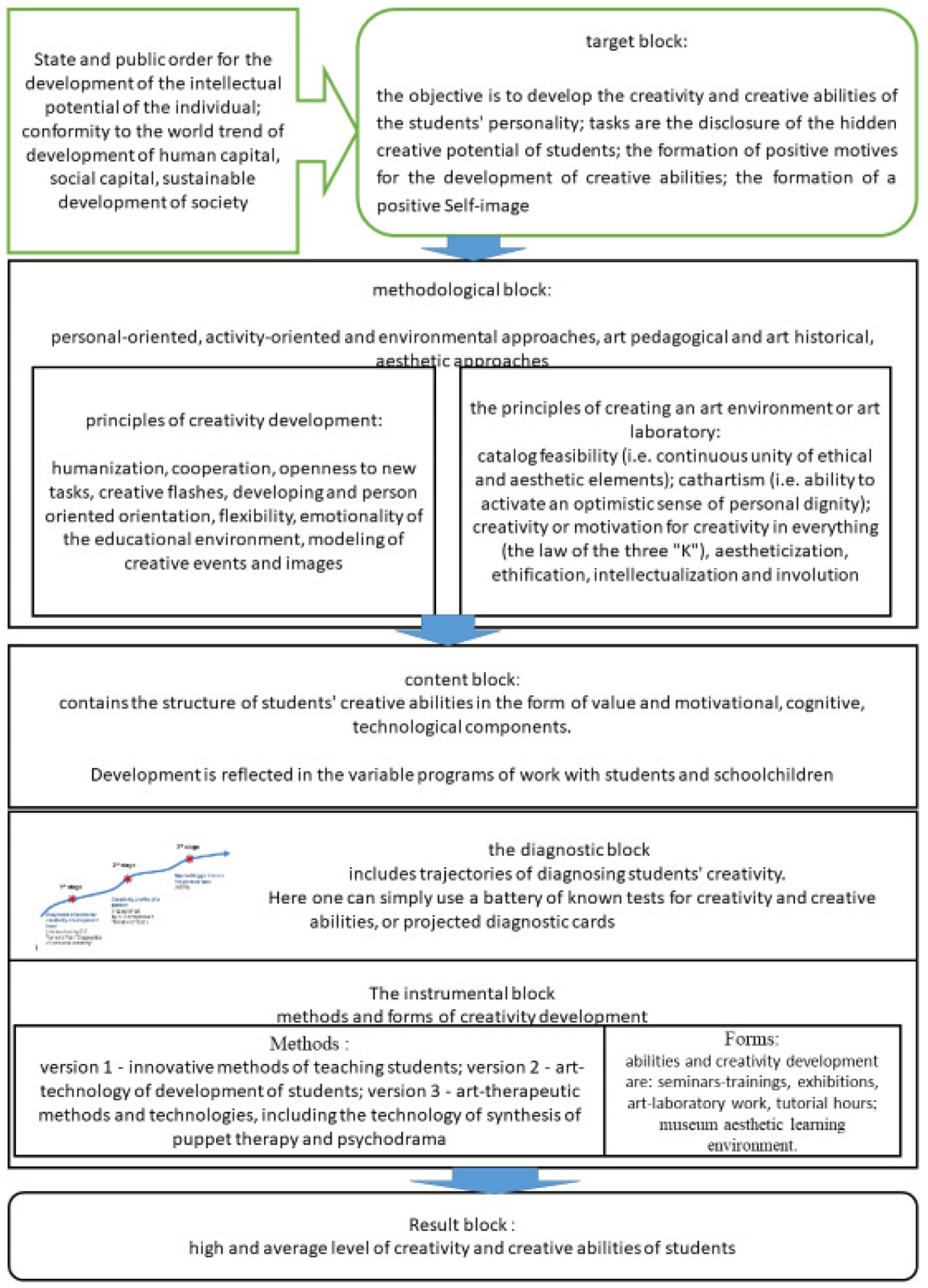

Figure 1 - Model for the development of creativity and creative abilities of students 
Result block: high and average level of creativity and creative abilities of students.

The model has been tested not only within the walls of the university, but also in the schools of Almaty.

In our opinion, the most relevant role in creativity development can be assigned to Art Teaching. For the development of Art Teaching, the fundamentals of Art Teaching and Art Therapy have been studied. It should be noted that research is currently being actively conducted in Kazakhstan in the field of Art Teaching and Art Therapy, with over 20 articles published in the recent 2 years, including in KazNU Bulletin - Pedagogical Series [6-7], new textbooks byYe. K. Isakova, A. N. Sbitneva [8], Z. B. Madaliyeva [9] and others.

According to Ye. K. Iskakova \& A. N. Sbitneva, 'Art Teaching is a synthesis of two areas of knowledge - Art \& Teaching, providing the development of theory and practice of correctional teaching process of children artistic development' [8]. At the same time, in the manual, the authors limit the application scope it to children with special abilities -in special education areas. In our opinion, Art Teaching has a wider understanding and application. Thus, it would be appropriate to paraphrase the definition in the following way 'Art Teaching is the science of educating individuals through the means of Art.'

The main roles of Art Teaching areas follows [8]:

- culturological, conditioned by the objective connection between individuals and culture as a system of values, human development through mastering and creating the artistic culture;

- educational, focusing on human development and exploring its being through Art, ensuring knowledge acquisition in the field of Art and practical skills behind artistic activity;

- upbringing - formation of moral and aesthetic, communicative $\&$ reflective basis of personality and promoting socio-cultural adaptation through Art;

- corrective-attributable to prevention, correction and compensation of development deficiencies [8];

- relaxation and rehabilitation - restoring human energy.

In our opinion, Art Teaching performs the function of creating the conditions for relaxation with a high rehabilitation capacity.

The goal of Art Teaching is children artistic development and the formation of the basics of artistic culture, social adaptation of human through Art [8].

Authors Ye. K. Isakova, A. N. Sbitneva in the manual - 'Art Teaching' [8] have combined general pedagogical principles, corrective pedagog- ics principles activity, principles of artistic \& aesthetic development. In particular, the principles of artistic \& aesthetic development include the following:

1) the principle of universal and compulsory nature of artistic \& aesthetic development;

2) the principle of scientific approach to student artistic \& aesthetic development;

3 ) the principle of close relationship between individual artistic\& aesthetic activities and the surrounding life and Art;

4) the principle of cultural appropriateness assumes the unity of popular culture and achievements of the global artistic culture;

5) the principle of comprehensive approach to individual artistic development by means of various Art types;

6) the principle of artistic correction.

The methods of Art Teaching are as follows: conversations, essays on emotional experiences, role-plays, aesthetic action exercises.

Promoting positive motivation in relation to artistic activity is achieved through the following:

- showing the finished piece of work - showing the activity deliverable such as a drawing, appliqué, modeling; tales, poems, singing or dancing performance;

- use of creative assignments (essays, riddles, dance composition etc.);

- performance of amusement exercises;

- performing game activities;

- success story imitation;

- working with special and non-standard material in Art activity lessons;

- attending and taking part in cultural and recreational activities [8].

A robust foundation of Art Teaching is Art Therapy, being a part of Psychology. Researcher L. D. Lebedeva notes that 'Art Therapy' according to professional teaching interpretation, is understood as concern about the emotional well-being and psychological health of an individual, group or team,by means of artistic activity (spontaneous drawing in combination with other forms of creativity)' [10]. We would like to stress that 'The teaching focus of Art Therapyis of non-clinical nature which is designed for an assumingly healthy person' (Lebedeva, 2001).

The main roles of Art Therapy are as follows:

- cathartic (purifying, relieving from negative conditions);

- regulatory (overcoming neuro-psychological stress, regulation of psychosomatic processes, shaping positive state of mind); 
- communicative \& reflexive (providing correction of communication disorders, normalization of interpersonal behavior, self-esteem).

In theory, the following Art Therapy modalities are covered: creative ideas, reflecting emotions onto a product (painting, modelling, art product), sublimation concepts; projective representations [3]; coaching etc.

P. Miteva emphasizes the triune of Art Therapy's therapeutic factors: artistic expression and impression, psychotherapeutic and group relationships, verbal and nonverbal feedback.

Art Technology is an emerging method inArt Teaching. Art Technology is a system of methods and techniques of artistic creativity, which contributes to self-expression and personal development [11]. The Russian researcher I.Ye. Shkil defines Art Technology as 'methods using non-verbal language of Art for for the development of an individualthat provides the opportunity to deal with deeper aspects of spiritual life,inner reality, shaped by thoughts, feelings, perceptions and life experiences.' According to the theory, the creation of artistic images serving as a base for Art Technologyto rest on, assists in understanding the self, self-expressing, thus, a much happier life [12].

Another author, S.V. Starikova gives the following definition to Art Technology- 'a combination of Art and methods of artistic and creative activity to achieve educational goals' [13].

Current teaching environment in universities enabled us to make use of a wide range of Art Technology. It uncovers philosophical ideas about the world in particular sensory forms, enablespassing the edge of the possible and the impossible through the game. Such 'assumed circumstances'may be the scope of subject, lesson subject, or text. Each of the three areas of culture-science, Art, real life, are the same 'proposed circumstances' [14].

The main idea behind applying Art Technology is to strengthen creative capacity in students, future experts on the basis of mastering the components of effective tolerant interaction, as well as skills to come up with meaningful creative educational environment based on the principles of theatrical teaching, which stimulates professional development within the interdisciplinary integration modality based on the synthetic nature of the theater [14].

The role of teachers, psychologists, social educators is to keep child's psychological health. At present, Art Technology is actively applied in Kazakhstan and abroad to keep psychological health, overcome stress, and aggressiveness. When students who major in Teaching are trained in Al-Farabi Ka-
zNU, they actively develop their hands on experiences in the following domains of Art Technology:

- Visual Art Therapy (therapy involving visual creativity such as drawing, arts and crafts, etc.); collage; modeling; sand therapy (non-verbal form of psychological correction, where the focus is placed on creative self-expression, through which the inner tension mirroring and seeking self-development paths occur on an unconscious level); decoupage technique (is a technique for decorating a wide variety of items. The technique involves applying decoration, image or drawing onto an object, followed by coating the surface with varnish in order to ensure aesthetic look and durability); drawing on stones; storytelling (treatment by telling tales, where there is an element of joint discovery with the client of the knowledge residing inside him/her that is currently psychotherapeutic); Drama Therapy; card-making; Puppet Therapy.

Designing and applying Art Technology, in addition to stimulating the learning process and developing creativity in students, enable teachers to upgrade their teaching skills. The use of Art Technology is also a manifestation of teacher's creativity assisting in strengthening student creativity.

\section{Results and discussion \\ Synthesis of Psychodrama and Art Therapy to establish a new technology.}

Figure 2 shows the model of synthesis between Art Technology and Psychodrama developed by us through shared goals, objectives, principles, functions, and content.

The author of the Psychodrama method is Jacob Moreno. In the course of counseling a client becomes the protagonist (main character) of the drama he/she embodies on the stage, and can interact with other actors as directed by the therapist (drama director). The basic concepts of Psychodrama include the following: roles, spontaneity, tele, catharsis and insight.

The goal of Psychodrama is to implement individual theory or problem resolution for each session participant, regardless of whether he/ she is a protagonist (the main character), an actor performing a supporting role depicting a person on the stage who is important to the protagonist or someone from the audience [15].

Jacob Moreno defines the spontaneity of a person's reaction as 'certain extent of adequacy of a new situation or certain degree of novelty in relation to the previous situation.' The level of spontaneity is important in assessing the state of mental health, social competence or situational involvement. 
Spontaneity training is helping a person to 'get rid of the script', 'cliché biased behavior, and develop new personal qualities through the ability to understand and respond to new situations' [15].

Spontaneity is the naturalness or nondeliberateness of perception and reaction. When growing up, people tend to lose the naturalness in expressing their feelings and thoughts, spontaneity, under the influence of biases and clichés.

Spontaneity can be improved through the psychodramatic situation of 'here and now'. In such a situation, there is no past, no future, no distance. 'In client's present there combined the problems stemming from the past and the fear for the future.' This psychodramatic situation of 'here and now' is an important element of the therapy, and is necessary for achieving spontaneity.
Tele emerges as part of the spontaneous involvement of two or more people in the psychodramatic situation. In terms of its meaning, tele is close to the understanding of 'transference' or 'transfer'. In Greek, 'tele' means 'far', 'influence from a distance'. The tele, according to J. Moreno, is 'individuals sensing each other'; this is the 'cement that holds the group together'. In other words, tele becomes a kind of 'therapeutic love' [16]. Tele is 'a meeting of two: eye-to-eye, face to face. And when you're near, I'll take your eyes and put them in the place of mine, and you'll take my eyes and put them in the place of yours, so that I'll look at you with your eyes, and you'll look at me with mine' [15]. In other words, theis 'mutual' exchange of empathy and recognition of the other.

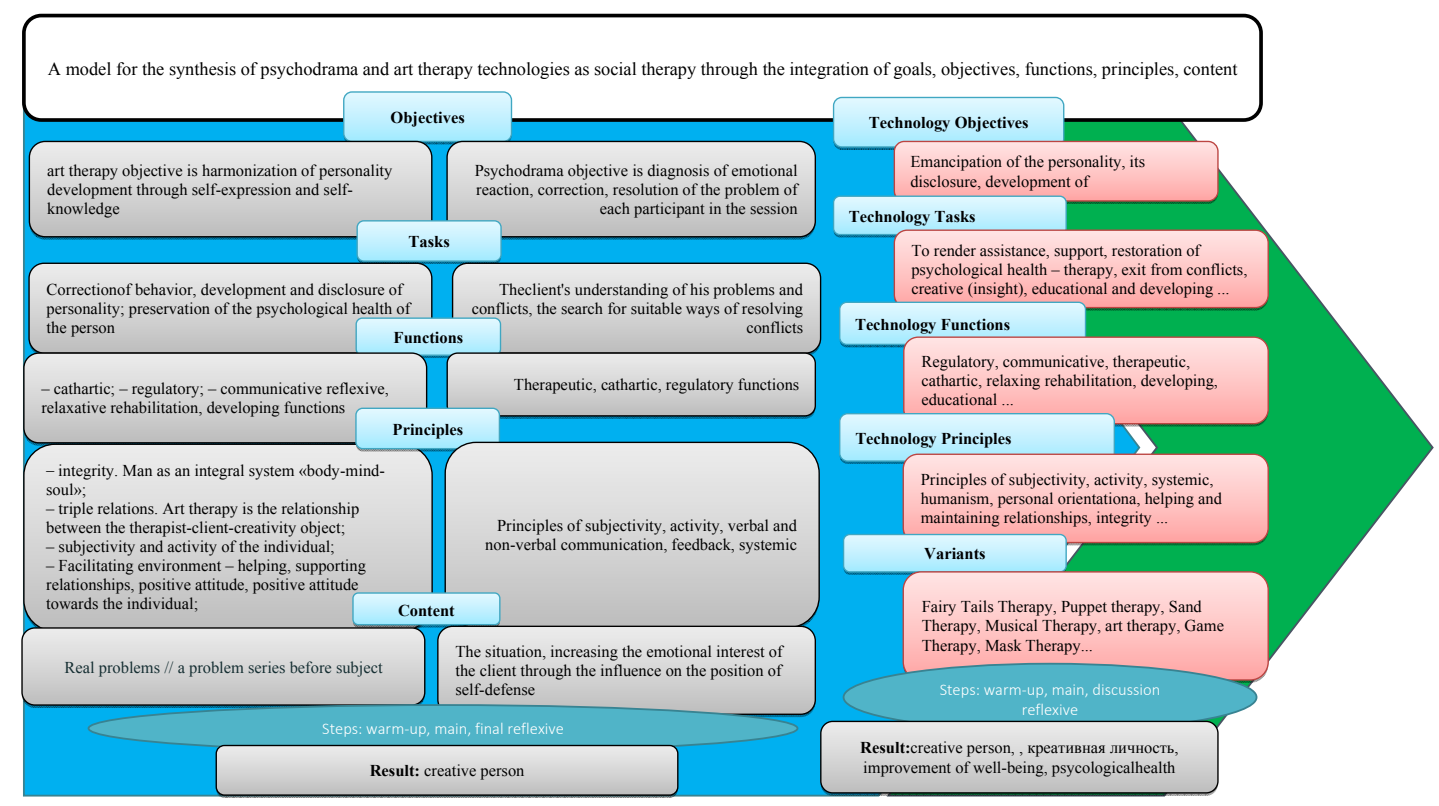

Figure 2 - Model for the synthesis of psychodrama and art therapy technologies

Catharsis and insight are the end products of interaction between spontaneity and the tele that arise in a situation and the achievements of a protagonist client.

Jacob Moreno assigns the Aristotelian meaning to catharsis. Aristotle developed the doctrine of catharsis asa concept of purifying the human soul in the course of Art perception. He pointed out that such purification (catharsis) is like getting rid of the unruly pathos, as well as subjective violence, therefore, the revised morality criteria, namely: an individual who in time of suffering has isolated himself/ herself from the social life, emerges from his/her private unity to universality, the latter is identified with life and aspirations of the society [16].

We synthesize a psychodrama and art therapy (elements of puppet therapy) to create a new technology. We carry out the integration component by component and propose it in the scheme: goals, objectives, functions, principles, content of stages and results (figure 2). It is detailed in the monograph published as the result of the project [17].

In psychotherapy, the method of puppet therapy as transferring experiences of the child to the subject, playing roles, developing self-awareness, solving conflict situations through creative activityis used. 
The goal of the technology is the loosening up of the personality, its disclosure, the development of creative abilities and creativity.

The objectives of technologyis to provide assistance, support, restoring of psychological health - therapy, exit from conflicts, then its are creative, educational and developing.

Functions of technologyare regulatory, communicative, therapeutic, cathartic, of relaxation and rehabilitation, developing, educational.

Principles for the design of technology are principles of subjectivity, activity, systemic, humanism, personalityorientation, helping and supporting relationships, integrity ...

We propose, on this basis, the following technology of puppet therapy.

Pre-prepared material is: old newspapers, magazines, scotch tape, scissors, you can line up, etc.

The first stage - warm-up: the removal of clamps, exercises for pedagogical artistry, the loosening up of the group, the exercise «Scrawl», etc.

The second stage is the main one. After acquiring a certain relaxedness and creating an atmosphere of creativity, the teacher offers students to put forward a problematic situation - the real problem with which they met at school, and which must be solved. For example, the pedagogical situation - the schoolgirl of 12 years began to go to school badly, lives with the grandmother, parents are on long foreign business trip. A student with her grandmother was summoned to school.

The teacher and the group discuss what roles will be played out. The students offered the roles of the Student, the Grandmother, the Class teacher, the Head teacher or the Director. The teacher added the role of Journalist (third independent part). Students divided the roles, it was allowed to discuss in pairs. That is, two students discussed and prepared the role, for example, of the Student, or of the Grandmother, or of the Journalist, etc. (in case there were more students in the group than the number of roles).

A task for students was to make puppets for the Student, Grandmother, Class teacher, Head teacher, Journalist from improvised material. For this, old newspapers, magazines, scotch, scissors, rulers and other materials were prepared. Students can prepare questionseach role to other. However usually the role interaction occurs spontaneously and naturally.

Students are given 20-25 minutes for preparation.

Then there is an improvisation - role-playing action. The teacher does not actually interfere in the staging, only can support the work of students, can ask questions in addition. Some cases were unexpected, for example, the student's improvised video presentation on TV about this situation in the school (on the one hand, the view from the outside, and on the second hand at the same time interest in solving the problem). Itbrought a fresh stream in the school process.

The third stage is final. There is a discussion of the staging and the problem, the search for solutions to the problem. Usually the discussion is very stormy, dynamic. The teacher can direct it with questions: who liked the role-play? Which doll is the most beautiful? What solutions were voiced during playback? What problems were raised? Who stimulated the resolution of the conflict? Who is the best performer? Has the main problem been solved? What lessons do we take out of the situation as teachers?

Applying Puppet Therapy technology occurs in creative environment, often with humor, laughter therapy involved, in a vivid, spontaneous manner, with decisions coming out suddenly, which is in line with the insight (figure 3).

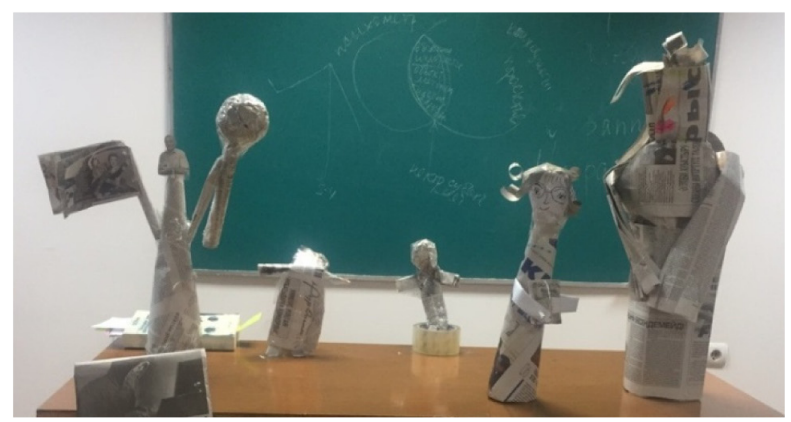

Figure 3 - Examples of dolls created by students in class

We note that performing the technology of puppet therapy occurs in a creative environment, often with humor and laugh therapy, actively, spontaneously, decisions sometimes come suddenly that corresponds to insight.

The technology was tested in the university - the Al-Farabi Kazakh National University with students of the specialty «Social pedagogy and self-knowledge», «Pedagogy and psychology» (26 students), magistral students of the specialty «Social pedagogy and self-cognition» (14 master's students). Also, a pilot study was carried out with high school students of the school No. 164 in Almaty together with Temirbekova F.V. The study involved 31 schoolchildren of 7-th and 8-th classes. The technology was used for schoolchil- 
dren to reduce aggressiveness, increase creativity, increase emotional stability. As a result of the use of technology, students' emotional stability, creativity were increased, and aggression was decreased $(26 \%)$.

Here is how students themselves assess the use of Art Technology in teaching:

'Art Technology urges interest in the subject, implementation of ideas and revealing inner feelings of a person' A.

'Art Technology stimulates motivation to learning, developingone's creativity, psychological hygiene, and self-control'.

'Art Technologyhelps to avoid routine work. It helps overcoming complexes and fears, develops spirituality and imagination, reinforces the faith in good' A.

\section{Conclusion}

As a result of the research, a model for creativity development in students has been designed including the following 7 blocks: public order, target, methodological, informative, diagnostic, instrumental, and effective one. It reflects three areas as follows: (1) use of innovative teaching methods, (2) use of Art Technology for capacity building in students, (3) technology of Puppet Therapy \& Psychodrama synthesis. Art Technology is actively applied in university learning process, both for creativity development in students, and for adapting students to university educational environment. In addition, teaching students Art Technology provides them a new tool for practical activities. These technologies are actively applied by students in the course of teaching 'Self-cognition' lessons.

\section{Литература}

1 Государственная программа развития образования и науки Республики Казахстан на 2016-2019 гг. - Астана: МОН PK, 2015

2 Развитие креативности и творческих способностей студентов как фактор повышения интеллектуального потенциала Казахстана: отчет о НИР (заключ.) / КазНУ им. аль-Фараби; рук. Мынбаева А.К. - Алматы, 2017. - 63 с.- № гос.регистрации 0115РК00743. - Инв. №0215РК01778.

3 Креативность и творческие способности личности: теории, принципы и карты развития: Монография / Мынбаева А.К., Вишневская А.В., Галимова Н.Р. - Алматы: Қазақ университеті, 2016. - 165 с.

Вишнякова Н. Креативная психопедагогика: Монография. - Ч. 1. - Минск, 1995.

5 Мирзалиева Э. Формирование нравственно-эстетической культуры учащихся гуманитарного колледжа во внеучебной деятельности: дис... к.п.н.: 13.00.01. - Бишкек, 2014

6 Айтбаева А.Б., Касен Г., Мырзаханова А. Перспективы развития и совершенствования содержания арт-педагогической и арт-терапевтической работы в Казахстане // Вестник КазНУ. Серия «Педагогические науки». - Journal of Educational Sciences, - 2017. - №1(50). -P. 28-35

7 Miteva P. Art-Projective Diagnostics in Training - the Possibility of Personal Development and Self-Cognition // Вестник КазНУ. Серия «Педагогические науки». - Journal of Educational Sciences, - 2017. - №3(52). - С. 8-16.

8 Исакова Е.К, Сбитнева А.Н. Арт-педагогика: учебно-методическое пособие. - Петропавловск: СКГУ им. М.Козыбаева, 2013. - 100 с.

9 Мадалиева 3.Б. Жалпыға арналған арт-терапия: оқу-әдістемелік кұрал. - Алматы: Қазақ университеті, 2016. - 160 с.

10 ЛебедеваЛ.Д. Практика арт-терапии: подходы, диагностика, система занятий/ Л.Д. Лебедева. - СПб.: Речь, 2003 ; - 256 с.

11 Мынбаева А.К., Смайлова А. Применение арт-технологий как средства формирования самооценки студентов в адаптационной период // Вестник КазНУ. Серия «Педагогические науки». - 2016. - №3(46).

12 Шкиль И.Е. Анализ применения арт-технологий как средства развития коммуникативной компетентности IT-специалистов // Психологические науки: теория и практика: материалы междунар. науч. конф. (г. Москва, февраль 2012 г.). М.: Буки-Веди, 2012. - С. 66-68.

13 Старикова С.В. Развитие профессиональной компетентности будущего социального педагога средствами арт-технологий: дис... канд.пед. наук. - М., 2008. - 200 с.

14 Соколова И.Ю., Сорокопуд Ю.В., Дьяченко А.С. Арт-технологии в профессионально личностном становлении специалиста // Новый Университет. Серия «Актуальные проблемы гуманитарных и общественных наук». - 2012. - №11-12(20-21).

15 Теория личности сквозь призму психодраммы // Психодрама и групповой процесс / под ред. И.А. Гринбург. - М., 1993. - C. 4-15.

16 Семенова В.В. Психодрама Морено. О методе // Электронный ресурc http://www.group-analysis.ru/psychodrama/psychodrama moreno.php Режим доступа: 15.10.2016

17 Арт-педагогика. Дидактическая креативность педагога: монография / Мынбаева А.К., Сеилханова М., Смайлова А. - Алматы: Қазақ университеті, 2016.

\section{References}

1 State Program for the Development of Education and Science in the Republic of Kazakhstan for 2016-2019 (2015). Astana, MES RK. 
2 Development of creativity and creative abilities of students as a factor of increasing the intellectual potential of Kazakhstan: report on research (2017, Report No0217RK01300). Al-Farabi KazNU; head Mynbayeva A.K. Almaty, 94. State registration number 0115RK00743.

3 Vishnyakova, N. (1995). Creative psycho-pedagogy: Monograph. Part 1. Minsk.

4 Mirzalieva, E. (2014). Formation of the moral and aesthetic culture of students of the liberal arts college in extracurricular activities: dissertation .... candidate of pedagogical sciences: 13.00.01. Bishkek.

5 Aitbayeva, A., Kassen, G. \& Myrzakhanova, A. (2017). Prospects for the development and improvement of the content of art pedagogical and art-therapeutical work in Kazakstan. Bulleten KazNU. Journal of Educational Sciences, 52, 3, 8-16.

6 Miteva P. (2017). Art-Projective Diagnostics in Training - the Possibility of Personal Development and Self-Cognition. Bulleten KazNU. Journal of Educational Sciences, 53, 8-16.

7 Isakova, E.K. \& Sbitneva, A.N. (2013). Art pedagogy: educational-methodical manual. Petropavlovsk: M. Kozybaev SKGU, 100.

8 Madaliyeva, Z.B. (2016). Zhalpyға arnalғan art therapy. Almaty, Қазақ университеті, 160.

9 Art pedagogy. Didactic creativity of the teacher: monograph / Mynbayeva AK, Seilkhanova M., Smaylova A. - Almaty: Kazakh University, 2017.

10 Mynbayeva, AK \& Smaylova, A. (2016). The use of art technologies as a means of forming students' self-esteem in the adaptation period. Bulletin of KazNU. Journal of Educational Sciences, 46, 3. 256.

11 Lebedeva L.D. (2003). The practice of art therapy: approaches, diagnostics, system of occupations. St. Petersburg, Speech,

12 Shkil I.E. (2012). Analysis of the application of art technologies as a means of developing the communicative competence of IT specialists. In: Psychological sciences: theory and practice: materials of the international. sci. Conf. (Moscow, February 2012). Moscow: Buki-Vedi, 66-68.

13 Starikova S.V. (2008). The development of professional competence of the future social educator with the means of art technologies (Unpublished doctoral dissertation of pedagogical sciences). Moscow, 200.

14 Sokolova I.Yu., Sorokopud Yu.V. \& Dyachenko A.S. (2012). Art-technologies in professionally personal formation of a specialist. New University. Series «Actual problems of the humanities and social sciences», 11-12 (20-21).

15 Theory of personality through the prism of psychodrama (1993). In: Greenburg I.A. (ed.) Psychodrama and group process. Moscow, 4-15.

16 Semenova V.V. (2016, 15 Oct). Moreno's psychodrama. On the method. Retrieved from http://www.group-analysis.ru/ psychodrama/psychodrama_moreno.php 